\title{
Insulin-Like Growth Factor and Epidermal Growth Factor Treatment: New Approaches to Protecting Steatotic Livers against Ischemia-Reperfusion Injury
}

Araní Casillas-Ramírez, Amine Zaouali, Susagna Padrissa-Altés, Ismail Ben Mosbah, Anna Pertosa, Izabel Alfany-Fernández, Maria Bintanel-Morcillo, Carme Xaus, Antoni Rimola, Juan Rodés, Joan Roselló-Catafau and Carmen Peralta

Endocrinology 2009 150:3153-3161 originally published online Mar 12, 2009; , doi: 10.1210/en.2008-1458

To subscribe to Endocrinology or any of the other journals published by The Endocrine Society please go to: http://endo.endojournals.org//subscriptions/
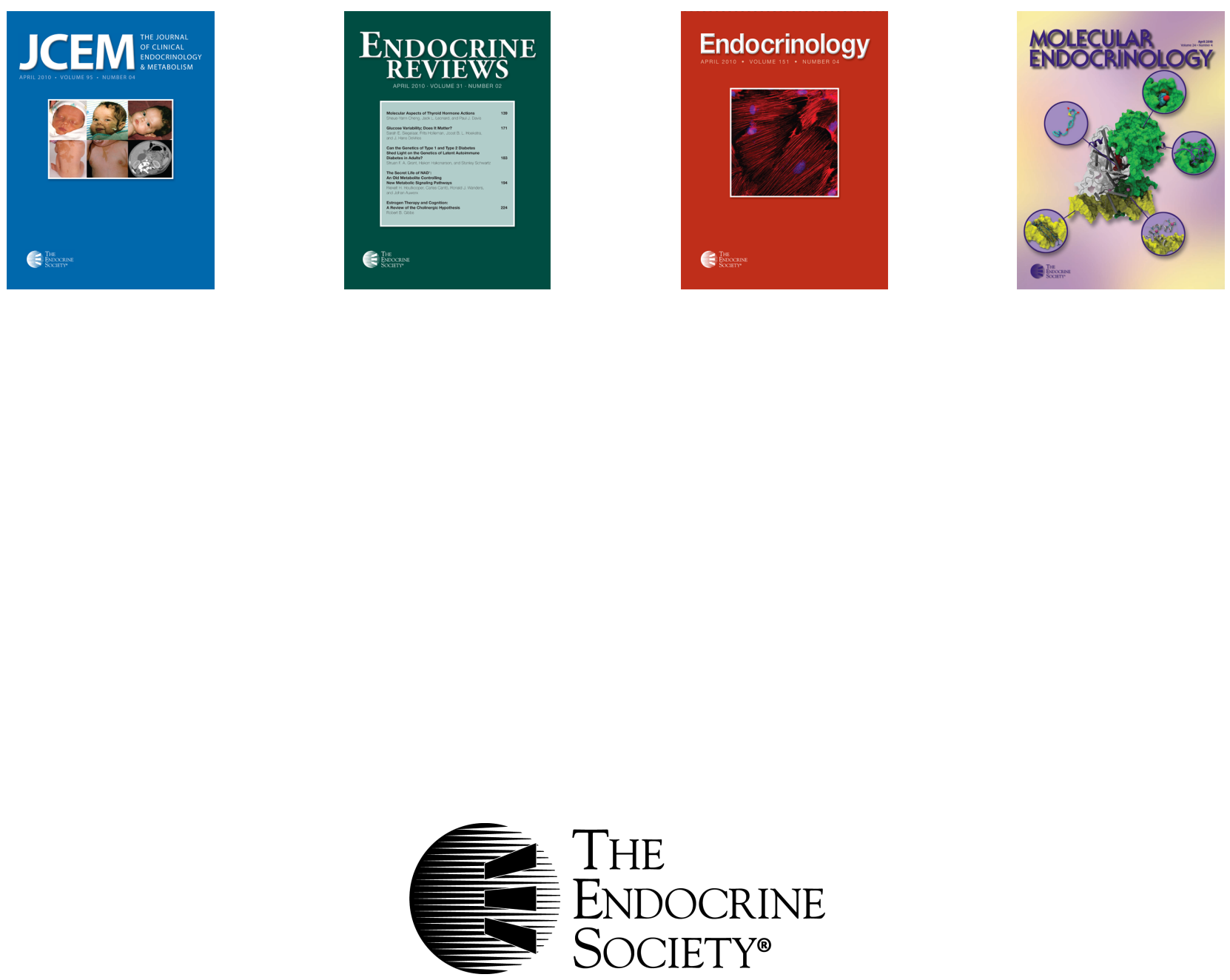


\title{
Insulin-Like Growth Factor and Epidermal Growth Factor Treatment: New Approaches to Protecting Steatotic Livers against Ischemia-Reperfusion Injury
}

\author{
Araní Casillas-Ramírez, * Amine Zaouali, * Susagna Padrissa-Altés, Ismail Ben Mosbah, \\ Anna Pertosa, Izabel Alfany-Fernández, Maria Bintanel-Morcillo, Carme Xaus, \\ Antoni Rimola, Juan Rodés, Joan Roselló-Catafau, and Carmen Peralta
}

\begin{abstract}
Unitat de Transplantament de Fetge i Viabilitat de I'Empelt (A.C.-R., I.A.-F., M.B.-M., J.R.-C., C.P.), Institut d' Investigaciones Biomèdiques August Pi i Sunyer; Experimental Hepatic Ischemia-Reperfusion Unit (A.Z., S.P.-A., I.B.M., A.P., C.X., J.R.-C.), Consejo Superior de Investigaciones Científicas; Centro de Investigaciones Biomédicas Esther Koplowitz (A.R., J.R., J.R.-C., C.P.), Centro de Investigación Biomédica en Red en el Área temática de Enfermedades Hepáticas y Digestivas, Instituto de Salud Carlos III; and Liver Unit (A.R., J.R.), Hospital Clinic Universitari, E-08036 Barcelona, Spain
\end{abstract}

\begin{abstract}
Hepatic steatosis is a major risk factor in ischemia-reperfusion (I/R). IGF-binding proteins (IGFBPs) modulate IGF-I action by transporting circulating IGF-I to its sites of action. Epidermal growth factor (EGF) stimulates IGF-I synthesis in vitro. We examined the effect of IGF-I and EGF treatment, separately or in combination, on the vulnerability of steatotic livers to I/R. Our results indicated that I/R impaired IGF-I synthesis only in steatotic livers. Only when a high dose of IGF-I (400 $\mu \mathrm{g} / \mathrm{kg})$ was given to obese animals did they show high circulating IGF-I:IGFBP levels, increased hepatic IGF-I levels, and protection against damage. In lean animals, a dose of $100 \mu \mathrm{g} / \mathrm{kg}$ IGF-I protected nonsteatotic livers. Our results indicated that the combined administration of IGF-I and EGF resulted in hepatic injury parameters in both liver types similar to that obtained by IGF-I and EGF separately. IGF-I increased egf expression in both liver types. The beneficial role of EGF on hepatic I/R injury may be attributable to $\mathrm{p} 38$ inhibition in nonsteatotic livers and to PPAR $\gamma$ overexpression in steatotic livers. In conclusion, IGF-I and EGF may constitute new pharmacological strategies to reduce the inherent susceptibility of steatotic livers to I/R injury. (Endocrinology 150: 3153-3161, 2009)
\end{abstract}

$\mathbf{H}$ epatic steatosis is a major risk factor after liver surgery because steatotic livers show poor tolerance to ischemiareperfusion (I/R) (1). Operative mortality associated with steatosis exceeds $14 \%$ after major resection compared with $2 \%$ for healthy livers $(2,3)$. In the case of transplantation, steatotic grafts are associated with a primary nonfunction rate of $60 \%$ compared with less than $5 \%$ for nonsteatotic grafts $(4,5)$. Therefore, developing protective strategies to minimize the adverse effects of $\mathrm{I} / \mathrm{R}$ injury in steatotic livers is an urgent need.

IGF-I is member of the IGF superfamily and participates in numerous pathophysiological processes (6-9). The IGF-binding proteins (IGFBPs), which are abundant in the bloodstream, organs, and tissues act as major modulators of IGF-I action by transporting IGF-I to its sites of action $(7,10,11)$. Interaction between growth factor families is a field of grow-

$\overline{\text { ISSN Print 0013-7227 ISSN Online 1945-7170 }}$

Printed in U.S.A.

Copyright (@) 2009 by The Endocrine Society

doi: 10.1210/en.2008-1458 Received October 17, 2008. Accepted March 3, 2009.

First Published Online March 12, 2009

* A.C.-R. and A.Z. contributed equally to this work. ing interest. Various in vitro studies indicate that epidermal growth factor (EGF) stimulates IGF-I synthesis in renal cells and isolated hepatocytes (12-14).

To our knowledge, the beneficial effects of IGF-I on hepatic $\mathrm{I} / \mathrm{R}$ injury have been reported only in nonsteatotic livers (15), whereas the effects of EGF on hepatic I/R injury remain unknown. The first purpose of this study was to evaluate whether treatment with IGF-I and EGF could improve the poor tolerance of steatotic livers to I/R. Given that EGF enhances igf1 expression in several cell types (12-14), the second purpose of this study was to evaluate whether EGF provides a stimulus for igf1 expression in hepatic I/R. Finally, the third purpose of the present study was to evaluate the involvement of p38 MAPK (p38) and peroxisome proliferator-activated receptor- $\gamma(\operatorname{PPAR} \gamma)$ in the effects of IGF-I and EGF on hepatic I/R injury in steatotic and nonsteatotic livers.

Abbreviations: EGF, Epidermal growth factor; IGFBP, IGF-binding protein; I/R, ischemiareperfusion; Ln, lean; Ob, obese; PPAR $\gamma$, peroxisome proliferator-activated receptor- $\gamma$. 
This approach was based on 1) previous studies from our group revealing the key role of both $\mathrm{p} 38$ and PPAR $\gamma$ in nonsteatotic and steatotic livers, respectively, under I/R conditions $(16,17)$ and 2$)$ data reported in the literature indicating that IGF-I and EGF affect p38 and PPAR $\gamma$ in several different conditions (18-21). Our findings could lead to the design of new pharmacological strategies in liver surgery for reducing hepatic I/R injury.

\section{Materials and Methods}

\section{Experimental animals}

Homozygous (obese, Ob) and heterozygous (lean, Ln) Zucker rats (Iffa-Credo, Lábresle, France) aged 16-18 wk were used. Ob Zucker rats have a mutated leptin receptor and, as a consequence, are hyperphagic, obese, and hyperinsulinemic, because they are insulin resistant, but have normal blood glucose levels. Ob Zucker rats do not develop diabetes. Ln Zucker rats maintain a lean phenotype throughout life, with normal blood insulin and glucose levels $(22,23)$. Control experiments from our group confirmed that none of the drugs included in the present study altered the plasma insulin or glucose levels in Ob Zucker rats. Ob Zucker rats showed severe macrovesicular and microvesicular fatty infiltration in hepatocytes (60-70\% steatosis). Ln Zucker rats showed no evidence of steatosis. The animals were anesthetized with ketamine and xylazine (100 and $8 \mathrm{mg} / \mathrm{kg}$, respectively) (17). The study followed European Union regulations (ECC Directive 86/609) governing animal experiments.

\section{Experimental design}

All animals were randomly sorted into groups.

\section{Protocol 1: effects of IGF-I and EGF administration on hepatic $I / R$}

Animals were divided into five groups: 1 ) sham ( $\mathrm{n}=12$, six Ln and six $\mathrm{Ob}$ ), in which hepatic hilium vessels were dissected; $\mathrm{I} / \mathrm{R}(\mathrm{n}=12$, six $\mathrm{Ln}$ and six $\mathrm{Ob})$, in which $60 \mathrm{~min}$ partial $(70 \%)$ hepatic ischemia was followed by 24 h reperfusion (17); 3) subgroup 3.1, IGF-I (100) ( $\mathrm{n}=12$, six $\mathrm{Ln}$ and six $\mathrm{Ob}$ ), same as group 2 but treated with IGF-I at doses of 100 $\mu \mathrm{g} / \mathrm{kg}$ (every $12 \mathrm{~h}$ for two doses, starting immediately before surgical procedure) (24, 25), and subgroup 3.2, IGF-I (400) ( $\mathrm{n}=6 \mathrm{Ob}$ ), same as group 2 but treated with IGF-I at doses of $400 \mu \mathrm{g} / \mathrm{kg}$ (every $12 \mathrm{~h}$ for two doses, starting immediately before surgical procedure) $(24,25) ; 4) \mathrm{EGF}$ ( $\mathrm{n}=12$, six $\mathrm{Ln}$ and six $\mathrm{Ob}$ ), same as group 2 but treated with EGF at doses of $100 \mu \mathrm{g} / \mathrm{kg}$ (every $8 \mathrm{~h}$ for three doses, starting immediately before surgical procedure) (26); and 5) IGF-I+EGF ( $\mathrm{n}=12$, six $\mathrm{Ln}$ and six $\mathrm{Ob}$ ), same as group 2 but treated with IGF-I at doses of $100 \mu \mathrm{g} / \mathrm{kg}$ in Ln and $400 \mu \mathrm{g} / \mathrm{kg}$ in Ob and EGF at doses of $100 \mu \mathrm{g} / \mathrm{kg}$ for $\mathrm{Ln}$ and $\mathrm{Ob}$. The pretreatment times for IGF-I and EGF were as described above (24-26).

Preliminary studies from our group based on dose response demonstrated that the doses of IGF-I (100 $\mu \mathrm{g} / \mathrm{kg}$ for Ln and $400 \mu \mathrm{g} / \mathrm{kg}$ for Ob) and EGF ( $100 \mu \mathrm{g} / \mathrm{kg}$ for $\mathrm{Ln}$ and $\mathrm{Ob})$ were the most effective in protecting the two liver types against I/R damage.

\section{Protocol 2: role of p38 in the effects of EGF on hepatic I/R injury}

Animals were divided into three additional groups: 6) p38 inhibitor ( $\mathrm{n}=$ $6 \mathrm{Ln}$ ), same as group 2 but treated with SB203580, a p38 inhibitor, at a dose of $1 \mathrm{mg} / \mathrm{kg} 24 \mathrm{~h}$ before surgical procedure (27); 7) p38 activator ( $\mathrm{n}=$ $6 \mathrm{Ln}$ ), same as group 2 but treated with anisomycin, a p38 activator, at a dose of $0.1 \mathrm{mg} / \mathrm{kg} 24 \mathrm{~h}$ before surgical procedure (27); and 8) EGF+p38 activator $(\mathrm{n}=6 \mathrm{Ln})$, same as group 2 but treated with EGF at doses of $100 \mu \mathrm{g} / \mathrm{kg}$ and anisomycin, a p38 activator, at a dose of $0.1 \mathrm{mg} / \mathrm{kg} 24 \mathrm{~h}$ before surgical procedure (27). The pretreatment times for EGF were as described above (26).

\section{Protocol 3: role of PPAR $\gamma$ in the effects of EGF on hepatic I/R injury}

Again, animals were divided into three additional groups: 9) PPAR $\gamma$ antagonist $(\mathrm{n}=6 \mathrm{Ob}$ ), same as group 2 but treated with GW9662, a PPAR $\gamma$ antagonist, at a dose of $1 \mathrm{mg} / \mathrm{kg}$ before surgical procedure (17); 10) PPAR $\gamma$ agonist ( $\mathrm{n}=6 \mathrm{Ob}$ ), same as group 2 but treated with rosiglitazone, a PPAR $\gamma$ agonist, at a dose of $1.5 \mathrm{mg} / \mathrm{kg}$ before and after surgical procedure (17); and 11) EGF+PPAR $\gamma$ antagonist ( $\mathrm{n}=6 \mathrm{Ob}$ ), same as group 2 but treated with EGF at a dose of $100 \mu \mathrm{g} / \mathrm{kg}$ and GW9662, a PPAR $\gamma$ antagonist, at a dose of $1 \mathrm{mg} / \mathrm{kg}$ before surgical procedure (17). The pretreatment times for EGF were as described above (26).

Plasma and liver samples were collected after hepatic reperfusion.

\section{Quantitative RT-PCR}

Quantitative real-time PCR analysis was performed by the premade Assays-on-Demand TaqMan probes (Rn00710306_m1 for igf1, Rn00563336_m1 for egf, and Rn00667869_m1 for $\beta$-actin) (Applied Biosystems, Foster City, CA). The TaqMan gene expression assay was performed according to the manufacturer's protocol (Applied Biosystems).

\section{Western blotting of IGF-I, EGF, IGFBP-3, p38, PPAR $\gamma$, and $\boldsymbol{\beta}$-actin}

Western blotting was performed as described elsewhere $(16,17)$, using the following antibodies: IGF-I, EGF, and IGFBP-3 (Santa Cruz Biotechnology, Santa Cruz, CA) total p38 and phosphorylated p38 (Cell Signaling Technology Inc., Beverly, MA), PPAR- $\gamma$ (Abcam, UK), and $\beta$-ActIn (Sigma Chemical Co., St. Louis, MO).

\section{Biochemical determinations}

Transaminases were evaluated according to standard procedures. The concentration of total IGF-I in plasma was determined by a modified acid-ethanol $(0.25 \mathrm{~N} \mathrm{HCl} / 87.5 \%$ ethanol) procedure with cryoprecipitation. Then, total IGF-I in plasma was determined by ELISA kit from Immunodiagnostic Systems (Fountain Hills, AZ) according to the manufacturer's instructions. The plasma concentration of free IGF-I was determined by centrifugal ultrafiltration. Briefly, the plasma samples were diluted 1:5 with Krebs-Ringer bicarbonate buffer ( $\mathrm{pH} 7.4$, with 5\% BSA) and prefiltered through a $0.22-\mu \mathrm{m}$ filter (Millex-GV; Millipore, Molsheim, France) to remove debris. The prefiltered samples were then added to Amicon YMT 30 membranes and MPS-1 supporting devices (Amicon Division, W. R. Grace, Beverly, MA) and centrifuged at $300 \times$ $g$ at $37 \mathrm{C}$ for $100 \mathrm{~min}$. The ultrafiltrate was collected from $40-100 \mathrm{~min}$ centrifugation and used for the determination of IGF-I by an ELISA kit from Immunodiagnostic Systems following manufacturer's guidelines $(28,29)$. IGFBP-3 levels in plasma were determined by using an ELISA kit from Diagnostic Systems Laboratories (Webster, TX), according to manufacturer's instructions (30).

\section{Histology and red-oil staining}

Hematoxylin- and eosin-stained sections were evaluated as follows: grade 0 , minimal or no evidence of injury; grade 1 , mild injury consisting of cytoplasmic vacuolation and focal nuclear pyknosis; grade 2, moderate to severe injury with extensive nuclear pyknosis, cytoplasmic hypereosinophilia, and loss of intercellular borders; and grade 3, severe necrosis with disintegration of hepatic cords, hemorrhage, and neutrophil infiltration $(31,32)$. Steatosis in liver was evaluated by red-oil staining on frozen specimens, according to standard procedures.

\section{Statistics}

Data are expressed as means \pm SE and were compared statistically by ANOVA, followed by Student-Newman-Keuls test. $P<0.05$ was considered significant. 
A

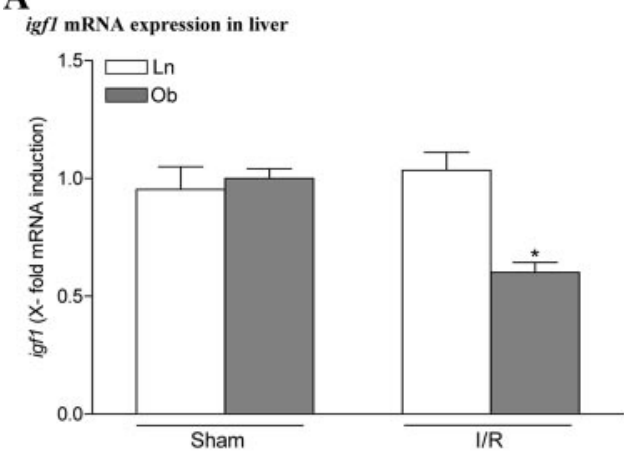

IGF-I protein levels in liver
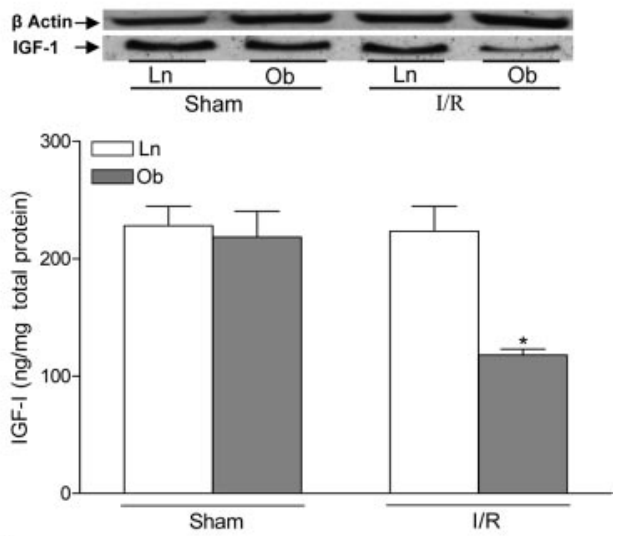

B

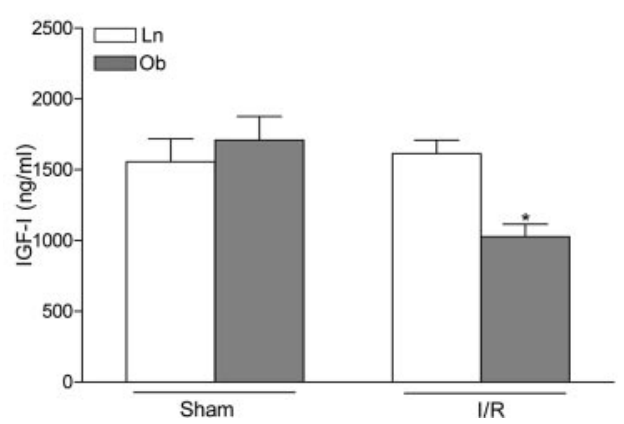

FIG. 1. A, igf1 mRNA expression and IGF-I protein levels in liver. For igf1 mRNA expression in liver, PCR fluorescent signals for IGF-I were standardized to PCR fluorescent signals obtained from an endogenous reference ( $\beta$-actin).

Comparative and relative quantifications of igf1 gene products normalized to $\beta$-actin and control sham group were calculated by the $2^{-\Delta \Delta C T}$ method. For IGF-I protein levels in liver, representative Western blot (top) and densitometric analysis (bottom) were performed. B, IGF-I protein levels in plasma. ${ }^{*}, P<0.05$ vs. sham.

\section{Results}

\section{Effect of I/R on hepatic and circulating IGF-I}

In Ln animals, I/R resulted in hepatic igf1 mRNA and IGF-I protein levels that were similar to those of the sham group (Fig. 1A). However, in Ob animals, I/R reduced hepatic igf1 mRNA and IGF-I protein levels when compared with the sham group (Fig. 1A). Circulating IGF-I is mainly derived from the liver (33, 34). Our results indicated that IGF-I levels in plasma (Fig. 1B) showed a similar pattern to IGF-I observed in the liver (Fig. 1A).

\section{Effects of IGF-I administration on hepatic I/R}

In $\mathrm{Ln}$ animals, I/R resulted in total and free IGF-I in plasma that was similar to that in the sham group (Fig. 2A). In $\mathrm{Ob}$ animals, I/R reduced total and free IGF-I levels in plasma when compared with the sham group. IGF-I administration in Ln and $\mathrm{Ob}$ animals increased total and free plasma IGF-I levels when compared with the I/R group (Fig. 2A). IGFBPs act as major modulators of IGF-I action by transporting circulating IGF-I to their sites of action $(7,10,11)$. In Ln animals, I/R resulted in a percentage of IGF-I bound to IGFBPs (IGF-I:IGFBP complex) in plasma that was similar to that in the sham group (Fig. 2A). In $\mathrm{Ob}$ animals, I/R reduced IGF-I:IGFBP complex in plasma when compared with the sham group (Fig. 2A). As previously mentioned, in $\mathrm{Ob}$ animals, I/R reduced hepatic IGF-I protein levels when compared with the sham group (Fig. 2B). Transaminase and damage score values of the $\mathrm{I} / \mathrm{R}$ group were higher in steatotic livers than in nonsteatotic livers (Fig. 2C), indicating that steatotic livers are more vulnerable to hepatic I/R damage. The administration of IGF $(100 \mu \mathrm{g} / \mathrm{kg})$ in $\mathrm{Ln}$ animals increased the IGF-I:IGFBP complex in plasma compared with the I/R group or the sham group (Fig. 2A). This was associated with increased hepatic IGF-I levels (Fig. 2B) and reduced hepatic injury (Fig. $2 \mathrm{C})$. At the same dose $(100 \mu \mathrm{g} / \mathrm{kg})$, IGF-I administration in $\mathrm{Ob}$ animals increased IGF-I:IGFBP complex in plasma over that recorded in the I/R group, although levels were similar to those of the sham group (Fig. 2A). This was not associated with increases in hepatic IGF-I levels (Fig. 2B) or protection against hepatic damage (Fig. 2C) when compared with the I/R group. However, the administration of IGF-I $(400 \mu \mathrm{g} / \mathrm{kg})$ in $\mathrm{Ob}$ animals resulted in a marked increase in circulating IGF-I:IGFBP levels (Fig. 2A), which was associated with increased hepatic IGF-I levels (Fig. 2B) and reduced hepatic injury (Fig. 2C).

\section{Effect of IGF-I on circulating and hepatic IGFBP-3}

IGFBP-3 binds the majority of circulating IGF-I ( 90\%) $(33,35)$.

In both $\mathrm{Ln}$ and $\mathrm{Ob}$ animals, I/R led to circulating IGFBP-3 levels similar to those of the sham group (Fig. 3A). The administration of IGF-I at the effective dose (100 and $400 \mu \mathrm{g} / \mathrm{kg}$ in $\mathrm{Ln}$ and $\mathrm{Ob}$ animals, respectively) reduced IGFBP-3 in plasma when compared with the I/R group. In both $\mathrm{Ln}$ and $\mathrm{Ob}$ animals, I/R led to hepatic IGFBP-3 levels similar to those of the sham group (Fig. 3A). IGF-I administration at the effective dose in both $\mathrm{Ln}$ and $\mathrm{Ob}$ animals increased hepatic IGFBP-3 protein levels when compared with the I/R group (Fig. 3A) but did not alter hepatic igfbp3 mRNA levels. Thus, the igfbp3 values (expressed as $\mathrm{x}$-fold mRNA induction) in nonsteatotic livers were $0.89 \pm 0.24$ and $0.88 \pm 0.25$ for I/R and IGF-I groups, respectively. The igfbp3 values in steatotic livers were $0.80 \pm 0.32$ and $0.87 \pm 0.34$ for I/R and IGF-I groups, respectively.

\section{Effect of IGF-I on hepatic EGF}

Pretreatment with EGF (at the same dose, $100 \mu \mathrm{g} / \mathrm{kg}$ in Ln and $\mathrm{Ob}$ ) reduced hepatic injury in both liver types when compared with the I/R group (Fig. 3B). The combined administration of IGF-I (at the effective dose, 100 and $400 \mu \mathrm{g} / \mathrm{kg}$ in $\mathrm{Ln}$ and $\mathrm{Ob}$, respectively) and EGF (100 $\mu \mathrm{g} / \mathrm{kg}$ in $\mathrm{Ln}$ and $\mathrm{Ob})$ resulted in similar hepatic injury parameters in both liver types to those obtained by IGF-I and EGF administration, separately (Fig. 3B). EGF administration in both $\mathrm{Ln}$ and $\mathrm{Ob}$ animals did not alter hepatic IGF-I, because the igf1 mRNA and IGF-I protein levels 
A

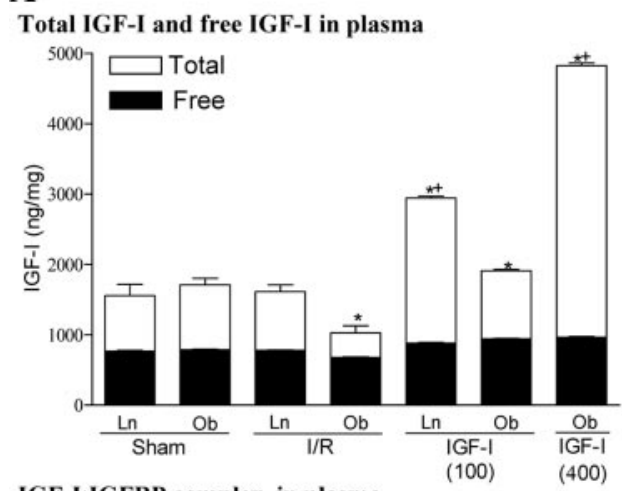

IGF-I:IGFBP complex in plasma

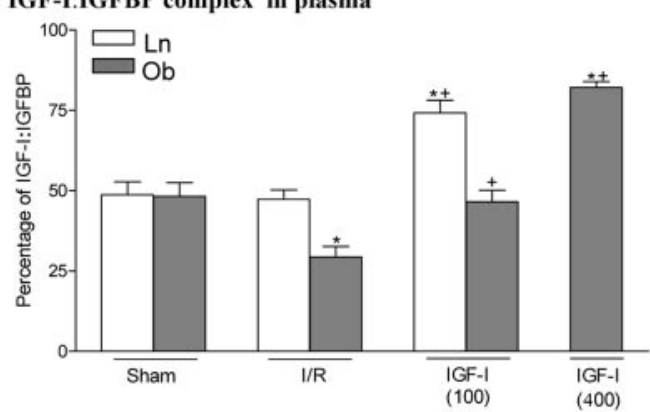

C

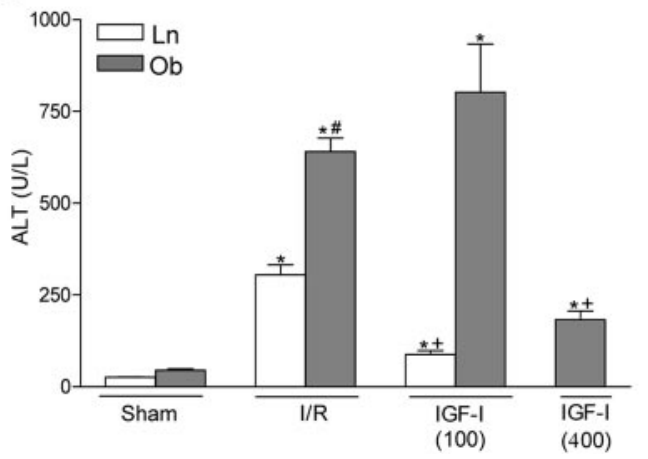

B
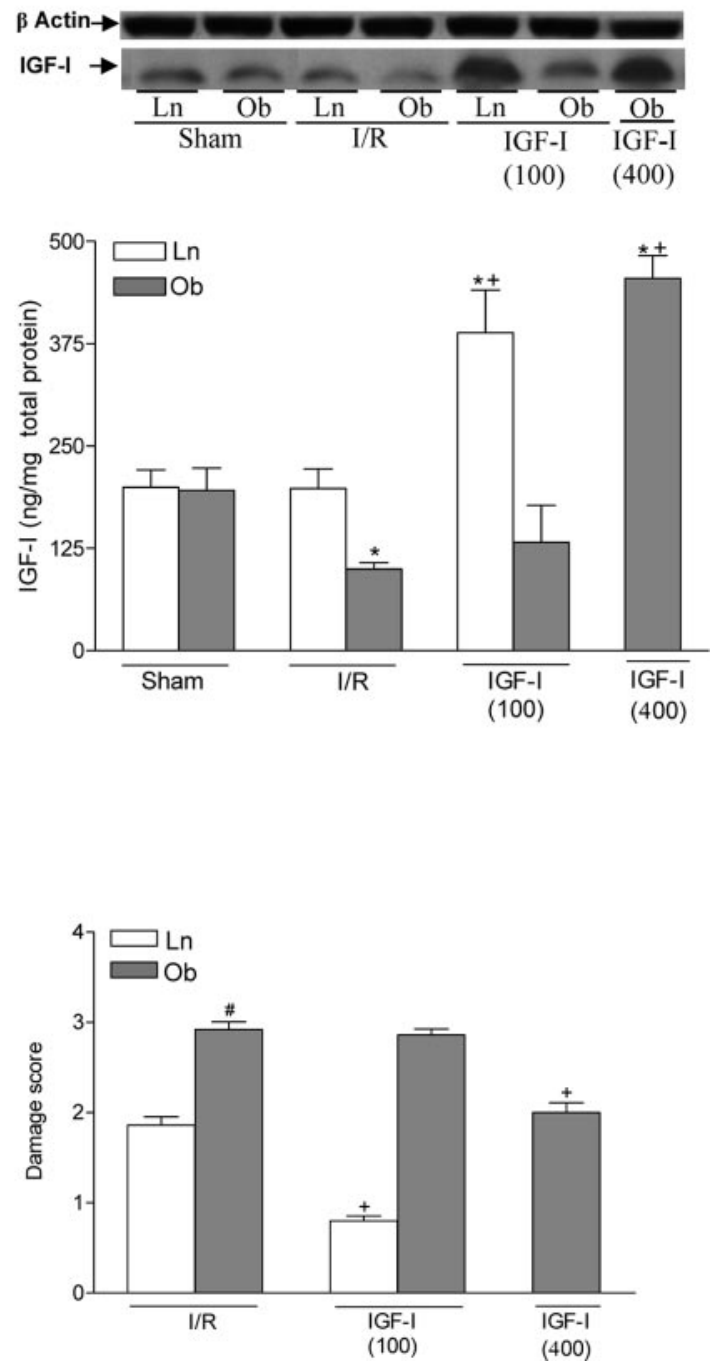

FIG. 2. A, Total IGF-I, free IGF-I, and IGF-I:IGFBP complexes in plasma. B, IGF-I protein levels in liver. Representative Western blot (top) and densitometric analysis (bottom) are shown. C, Hepatic injury (Alanine Aminotransferase levels and damage score). * $P<0.05$ vs. sham;,$+ P<0.05$ vs. I/R. Transaminase levels and damage score are significantly higher in the untreated $\mathrm{Ob}$ group than in the untreated $\operatorname{Ln}$ group $(\#, P<0.05)$.

observed in both liver types after EGF treatment were similar to those of the I/R group (Fig. 4A). However, IGF-I administration in both $\mathrm{Ln}$ and $\mathrm{Ob}$ animals (at the effective dose, 100 and 400 $\mu \mathrm{g} / \mathrm{kg}$ in Ln and $\mathrm{Ob}$, respectively) increased hepatic egf mRNA expression and EGF-I protein levels over those of the I/R group (Fig. 4B).

\section{Protective mechanisms of EGF in hepatic I/R}

$\mathrm{I} / \mathrm{R}$ increased phosphorylated $\mathrm{p} 38$ levels in both type of livers when compared with the sham group (Fig. 5A). The protein levels of total p38 were unchanged in all groups. EGF administration in Ln animals reduced hepatic phosphorylated p38 levels when compared with the I/R group. However, EGF administration in $\mathrm{Ob}$ animals resulted in hepatic phosphorylated $\mathrm{p} 38$ levels similar to those of the I/R group (Fig. 5A). The effect of EGF on PPAR $\gamma$ in the presence of steatosis was also evaluated. As previously reported (17), I/R induced changes in PPAR $\gamma$ levels only in steatotic livers (Fig. 5A). EGF administration in $\mathrm{Ob}$ animals increased PPAR $\gamma$ levels when compared with the I/R group. No changes in PPAR $\gamma$ were observed in nonsteatotic liver of any group compared with the sham group (Fig. 5A). Like EGF, IGF-I also reduced p38 levels in nonsteatotic livers and increased PPAR $\gamma$ levels in steatotic livers when compared with the I/R group (data not shown). This may be due to the fact that IGF-I increased EGF.

Next, the relevance of the changes in p38 and PPAR $\gamma$ induced by EGF treatment in nonsteatotic and steatotic livers, respectively, was also evaluated. First we showed that the increase in p38 induced by I/R had injurious effects on hepatic damage in nonsteatotic livers. Administration of p38 inhibitor in Ln animals reduced hepatic injury when compared with the I/R group (Fig. 5B). To test our hypothesis (that EGF exerts its action in nonsteatotic livers through p38 inhibition), we used a p38 activator at a dose that increased p38 levels to the same levels as those of the I/R group but not higher. We carried out control experiments to confirm that in all groups treated with p38 activator, 
A

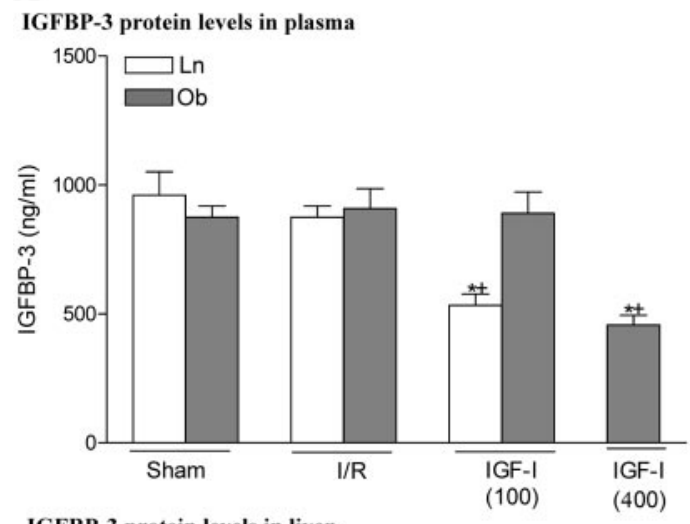

IGFBP-3 protein levels in liver
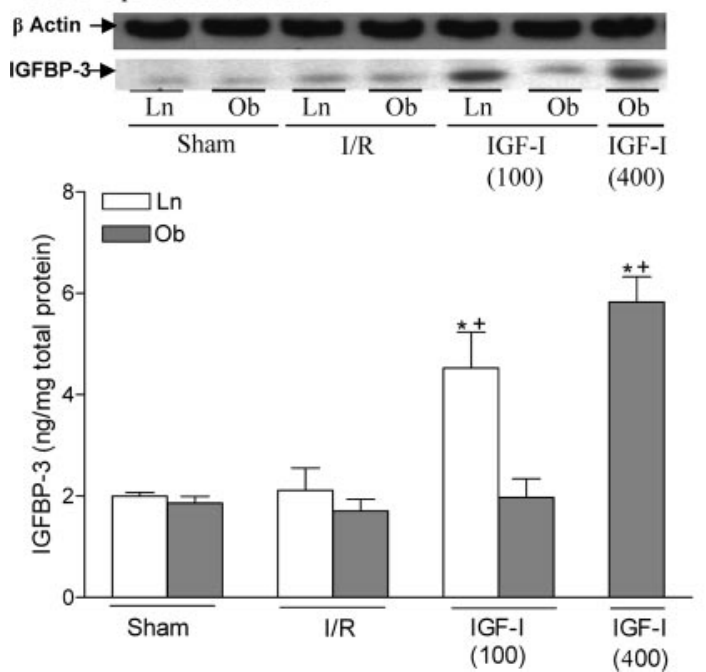

B
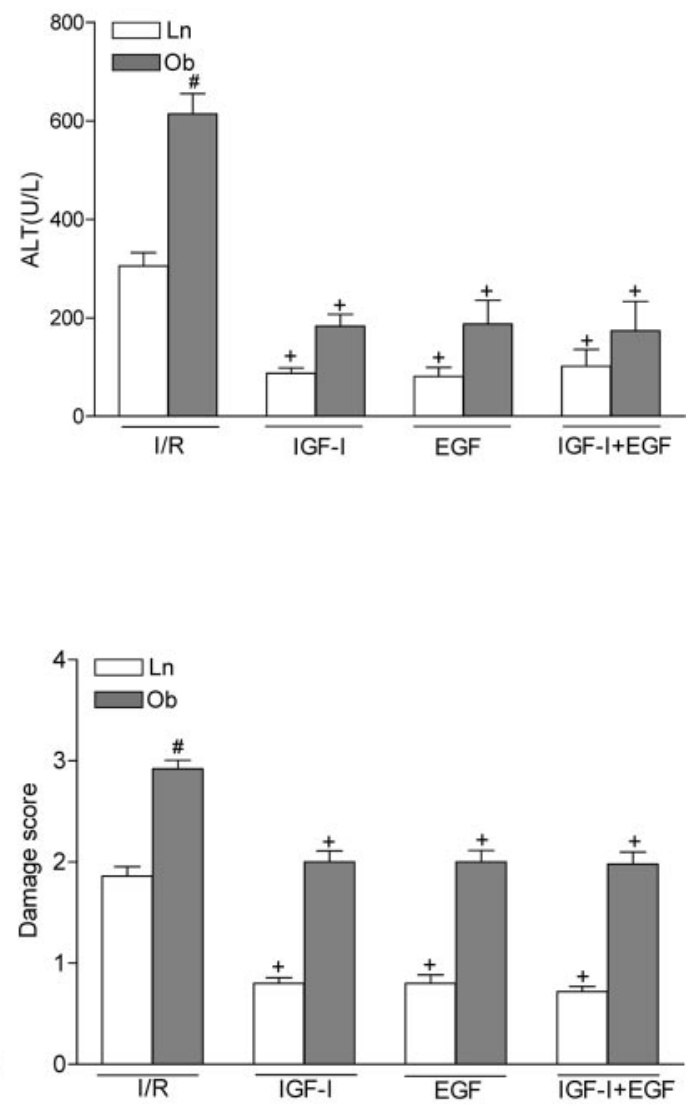

FIG. 3. A, IGFBP-3 protein levels in liver and plasma. For IGFBP-3 protein levels in liver, representative Western blot (top) and densitometric analysis (bottom) were performed. B, Effect of IGF-I and EGF administration on hepatic injury (alanine aminotransferase levels and damage score). ${ }^{*}, P<0.05$ vs. sham;,$+ P<0.05$ vs. I/R Transaminase levels and damage score are significantly higher in the untreated Ob group than in the untreated Ln group (\#, $P<0.05$ ). There were no significant differences in the hepatic injury parameters between IGF-I, EGF, and EGF+IGF groups.

p38 levels were similar to those of the I/R group (data not shown). Thus, the administration of $\mathrm{p} 38$ activator in $\mathrm{Ln}$ animals (p38 activator group) resulted in similar hepatic p38 levels to those of the I/R group (data not shown) and, consequently, similar parameters of hepatic injury to those of the I/R group (Fig. 5B). As previously mentioned, EGF administration in Ln animals (EGF group) reduced hepatic phosphorylated p38 levels with respect to those of the I/R group (Fig. 5A), and this was associated with reduced hepatic injury (Fig. 5B). However, the administration of both EGF and p38 activator in Ln animals (EGF+p38 group) resulted in hepatic p38 levels similar to those of the I/R group (data not shown), and this was associated with biochemical and histological parameters of hepatic injury that were similar to those of the I/R group (Fig. 5B). Thus, when p38 activator was administered, EGF pretreatment did not protect nonsteatotic livers against hepatic I/R injury.

Regarding PPAR $\gamma$, the slight but significant increase in PPAR $\gamma$ levels that occurred in steatotic livers as a consequence of I/R (Fig. 5A) had no effect on hepatic injury, because the administration of PPAR $\gamma$ antagonist in Ob animals (PPAR $\gamma$ antagonist group) resulted in hepatic injury parameters that were similar to those of the I/R group (Fig. 5B). Previous studies (17) reported that $\operatorname{PPAR} \gamma$ agonist pretreatment or strategies that increase PPAR $\gamma$ levels over those found in $\mathrm{I} / \mathrm{R}$ protect steatotic livers against hepatic I/R injury. PPAR $\gamma$ agonist administration in $\mathrm{Ob}$ animals (PPAR $\gamma$ agonist group) reduced hepatic injury when compared with the I/R group (Fig. 5B). As shown above, EGF administration in $\mathrm{Ob}$ animals (EGF group) increased hepatic PPAR $\gamma$ levels in steatotic livers over those found in the I/R group (Fig. 5A), and this was associated with reduced hepatic injury (Fig. 5B). The administration of both EGF and PPAR $\gamma$ antagonist in $\mathrm{Ob}$ animals (EGF+ PPAR $\gamma$ antagonist group) resulted in hepatic injury parameters that were similar to those of the $\mathrm{I} / \mathrm{R}$ group despite the presence of EGF (Fig. 5B).

\section{Discussion}

Hepatic synthesis and secretion of IGF-I is impaired in inflammatory conditions such as sepsis, endotoxemia, and cirrhosis (36-38). Our results, based on hepatic igf1 mRNA and IGF-I protein levels, indicate that synthesis of IGF-I is impaired in steatotic livers of $\mathrm{Ob}$ animals subjected to I/R. The decrease in circulating IGF-I observed in various liver disorders could result 
A

igfl mRNA expression in liver

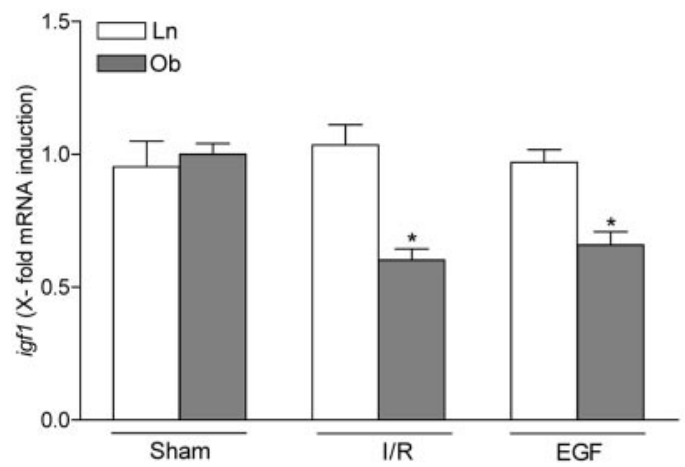

IGF-I protein levels in liver
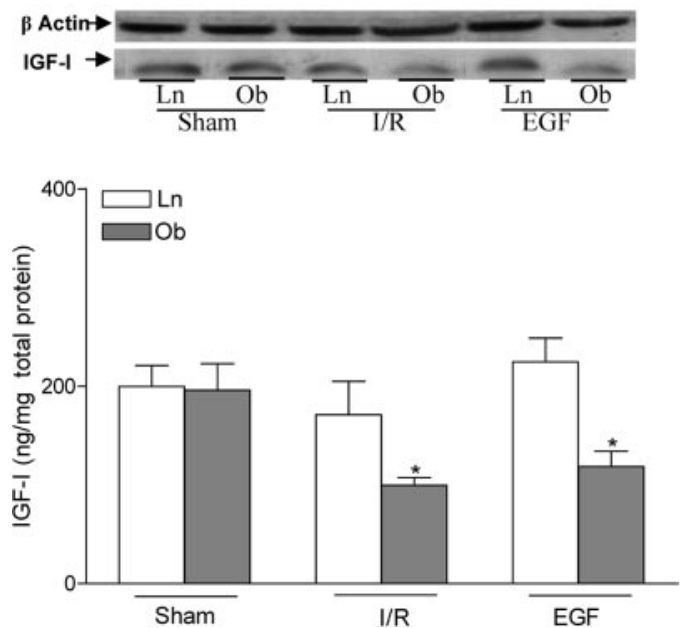

B

egf mRNA expression in liver

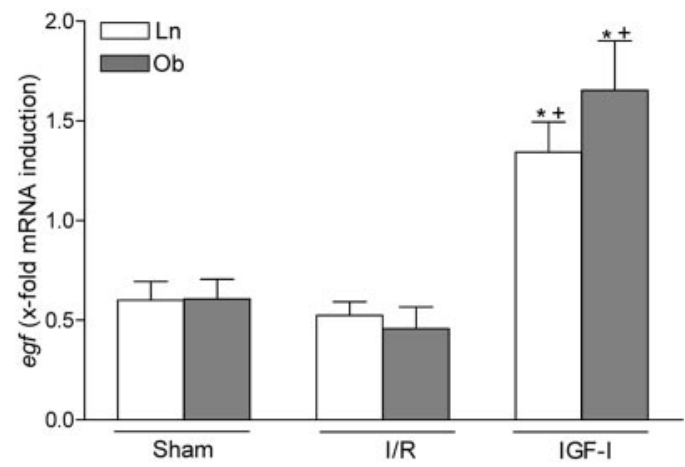

EGF protein levels in liver
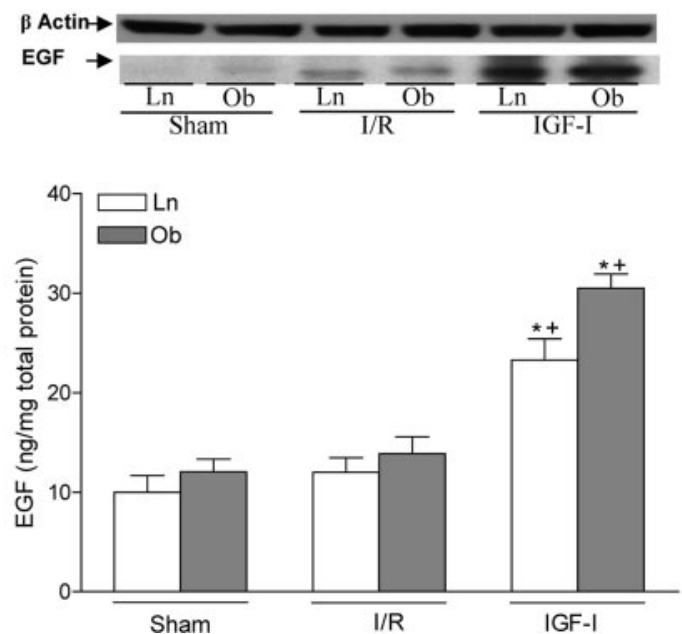

FIG. 4. A, Effect of EGF administration on igf1 mRNA expression and IGF-I protein levels in liver. B, Effect of IGF-I administration on egf mRNA expression and EGF protein levels in liver. For igf1 and egf mRNA expression in liver, PCR fluorescent signals for IGF-I and EGF were standardized to PCR fluorescent signals obtained from an endogenous reference ( $\beta$-actin). Comparative and relative quantifications of igf1 and egf gene products normalized to $\beta$-actin and control sham group were calculated by the $2^{-\Delta \Delta C T}$ method. For IGF-I and EGF protein levels in liver, representative Western blot (top) and densitometric analysis (bottom) were performed. $*, P<0.05$ vs. sham;,$+ P<0.05$ vs. I/R.

from a decrease in the rate of synthesis and an increase in the rate of removal from the blood $(28,37)$. The correlation between hepatic and circulating IGF-I indicates that the reduction in circulating IGF-I levels observed in Ob animals subjected to hepatic I/R could mainly be due to hepatic IGF-I synthesis reduction. Nevertheless, an increase in the rate of removal from the blood should not be ruled out.

The causes of the decrease in IGF-I synthesis observed in steatotic livers undergoing $\mathrm{I} / \mathrm{R}$ were not explored in this study. However, a failure in the GH signaling pathway in steatotic livers under $\mathrm{I} / \mathrm{R}$ conditions should not be ruled out. GH is released from the anterior pituitary gland, binds to its receptors in the liver, and thus, in turn synthesizes IGF-I (38). A decrease in GH secretion and alterations in the number of GH receptors have been observed in liver disorders caused by alcohol consumption, thermal injury, or Laron's syndrome. This leads to GH resistance in the liver, with a corresponding reduction in hepatic IGF-I synthesis $(28,39,40)$.

We show here that in contrast to Ln animals, IGF-I administration at the dose of $100 \mu \mathrm{g} / \mathrm{kg}$ in Ob animals was not associated with either an increase in hepatic IGF-I protein levels or protection against damage. Thus, a higher dose of IGF-I had to be administered in $\mathrm{Ob}$ animals to protect steatotic livers effectively. This could be explained, at least partially, by the impairment of IGF-I synthesis induced by I/R in steatotic livers.

IGFBP-3 binds most circulating IGF-I (41), but a smaller proportion of IGF-I is associated with other serum IGFBPs (IGFBP-1, -2, -4, -5, and -6) $(42,43)$. Surprisingly, this did not appear to occur in the conditions of the present study. According to our results, in plasma of the sham Ob group, total IGF-I levels were about $200 \mathrm{~nm}$, IGFBP-3 levels were about $30 \mathrm{~nm}$, and the percentage of IGF-I bound to IGFBPs was about $50 \%$. Considering that one molecule of IGF-I binds one molecule of IGFBP-3 $(44,45)$, this indicates that another IGFBP apart from IGFBP-3 must be present at unusually high concentration for $50 \%$ of IGF-I to be in complexes. Similarly, in plasma of Ob rats undergoing I/R and treated with IGF-I at the effective dose, total IGF-I levels were about $640 \mathrm{nM}$, IGFBP-3 levels were about $15 \mathrm{~nm}$, and the percentage of IGF-I bound to IGFBPs was $80 \%$. This indicates that another IGFBP apart from IGFBP-3 must be present at unusually high concentration for $80 \%$ of IGF-I to be in complexes. Thus, further research will be needed to identify the IG- 

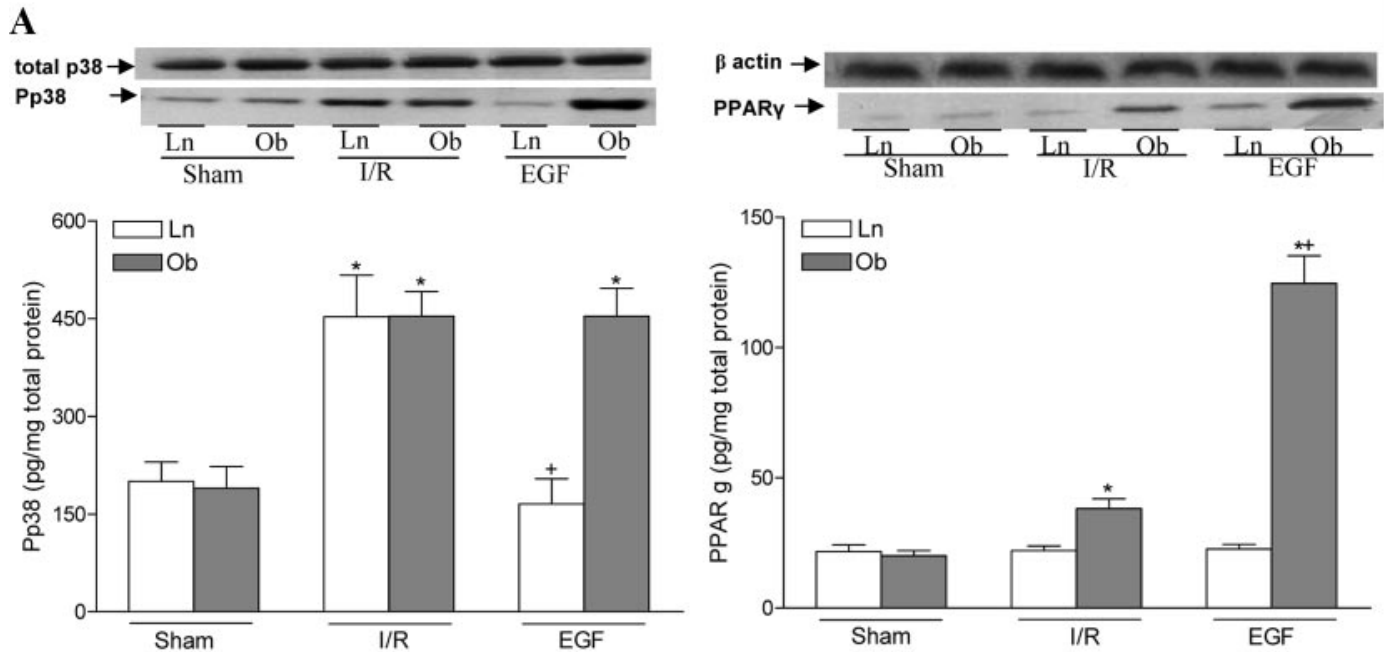

B

Pharmacological modulation of p38 in Ln rats
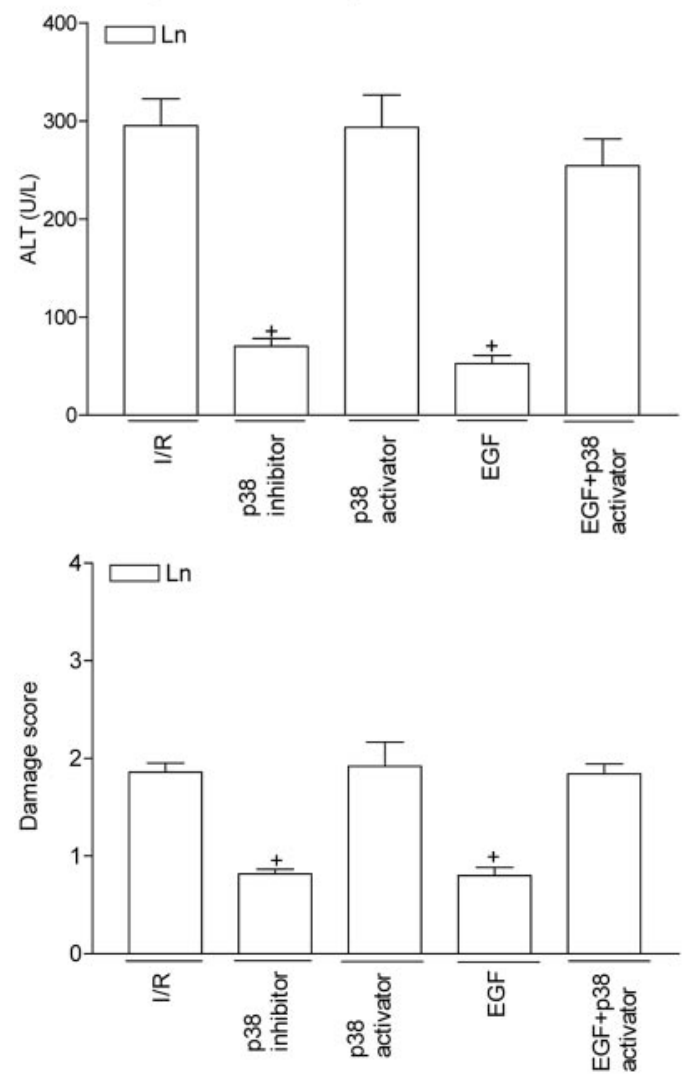

Pharmacological modulation of PPAR $\gamma$ in Ob rats
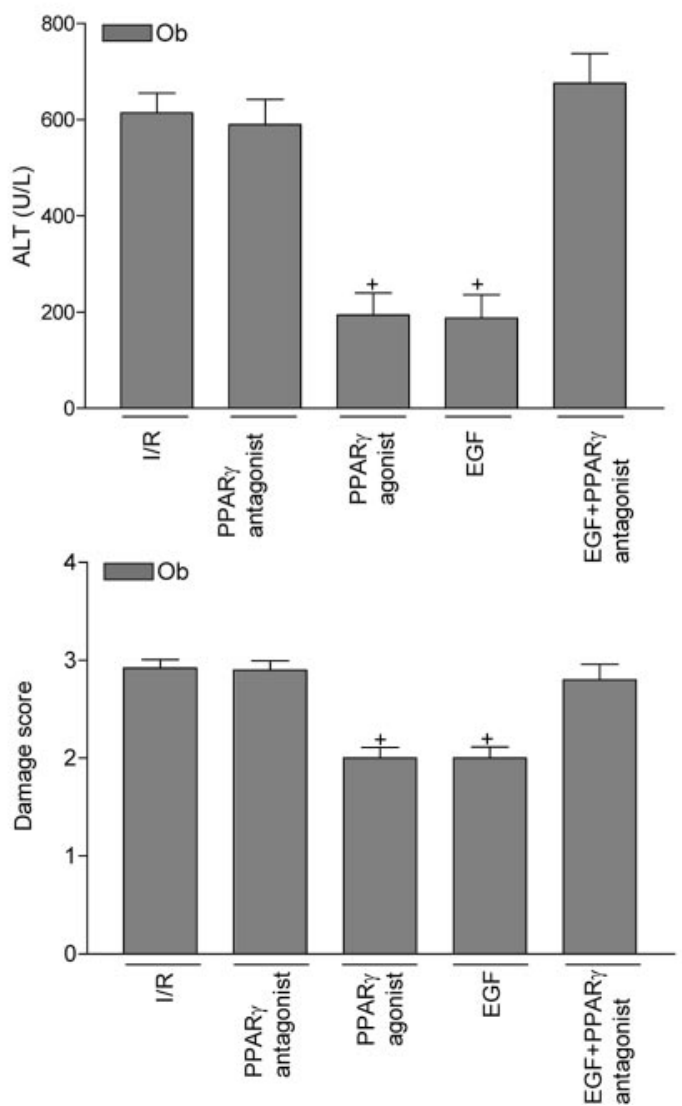

FIG. 5. A, Effect of EGF administration on phosphorylated p38 (Pp38) protein levels and PPAR $\gamma$ protein levels in liver. Representative Western blot (top) and densitometric analysis (bottom) are shown. B, Hepatic injury (alanine aminotransferase levels and damage score) after pharmacological modulation of p38 in nonsteatotic livers and PPAR $\gamma$ in steatotic livers. ${ }^{*}, P<0.05$ vs. sham;,$+ P<0.05$ vs. I/R.

FBPs other than IGFBP-3 that should be considered under warm hepatic I/R conditions in both liver types.

In addition to acting as a binding protein of circulating IGF-I, IGFBP-3 has been reported to have IGF-I-independent actions; IGFBP-3 inhibits cellular proliferation and enhances apoptosis by binding to the cell membrane (46-49). These effects of IGFBP-3 are injurious in conditions of hepatic I/R. Because our results showed that increases in hepatic IGFBP-3 were in parallel with hepatic protection, it seems unlikely that in the conditions evaluated herein, IGFBP-3 has IGF-independent effects. Further studies will be required to clarify why IGF-I administration increased hepatic IGF-I protein levels but reduced plasma IGFBP-3 levels, considering that IGF-I is one of the main positive regulators of IGFBP-3 levels $(50,51)$. Nevertheless, on the basis of previous reports in other pathologies, we hypothesize that a decrease in circulating IGFBP-3 could be explained, at least par- 
tially, by increased IGFBP-3 rate of clearance or enhanced IGFBP-3 proteolysis $(41,52)$.

It should be considered that IGF-I and EGF decrease hepatic $\mathrm{I} / \mathrm{R}$ injury but do not preserve the liver from $\mathrm{I} / \mathrm{R}$ injury. The latter is a complex process in which several mechanisms participate (53) but not all of which are affected by EGF and IGF-I. The ability of IGF-I and EGF to protect both liver types against I/R injury is of particular interest because numerous strategies that are effective in nonsteatotic livers may not be useful in the presence of steatosis $(31,53)$. It should be noted that the administration of EGF resulted in hepatic injury parameters similar to those obtained by IGF. However, EGF seems to be the most appropriate therapeutic strategy. Our main argument is that the IGF-I dose that protected against I/R injury is different for steatotic and nonsteatotic livers. This may be an obstacle to its therapeutic use in clinical practice. Moreover, it would appear to be more reasonable to administer the ultimate effecter of the cascade, EGF in this case, because its effects are more direct.

Herein we showed that the combined administration of IGF-I and EGF resulted in hepatic injury parameters in both liver types that were similar to those induced by IGF-I and EGF separately. Thus, a combination of IGF-I and EGF seems unnecessary to protect both liver types against I/R injury. Our results showed a potential relationship between IGF-I and EGF in both liver types under warm ischemic conditions. In contrast with the results obtained in different types of cells (12-14), EGF did not enhance igf1 expression in our conditions. The results reported here indicate that IGF-I induces egf expression in both steatotic and nonsteatotic livers under hepatic I/R conditions. Previous studies from our group revealed the key role of both $\mathrm{p} 38$ and PPAR $\gamma$ in nonsteatotic and steatotic livers, respectively, under I/R conditions $(16,17)$, and data reported in the literature have indicated that IGF-I and EGF affect p38 and PPAR $\gamma$ in several different conditions (18-21). In the present study, we hypothesize that the benefits of EGF on hepatic I/R injury could be explained, at least partially, by a reduction in $\mathrm{p} 38$ activation in nonsteatotic livers and by overexpression of PPAR $\gamma$ in the presence of steatosis. Thus, EGF protected both liver types, possibly by different mechanisms. This is in line with reports indicating that the multiple intracellular signaling induced by EGF depends on cell type. Moreover, the EGF signaling pathway in the same cell type may result in completely different effects depending on numerous factors including the concentration of growth factor, the number of receptors displayed on the cell surface, and docking and target proteins and their initial activity state (54-56). Taking these observations into account, and the structural and functional differences between hepatocytes with or without fatty infiltration (57-59), it is not surprising that our results show a differential effect of EGF on $\mathrm{p} 38$ and PPAR $\gamma$, depending on the type of liver.

In conclusion, pharmacological strategies based on IGF-I and EGF administration could open new pathways for protecting steatotic livers against $\mathrm{I} / \mathrm{R}$, although they do not need to be administered in combination. Moreover, EGF administration could be a more appropriate clinical therapy because EGF protected both liver types at the same dose and its effects are more direct than IGF-I. Finally, EGF protected the liver against I/R injury by reducing p38 activation in nonsteatotic livers and inducing PPAR $\gamma$ overexpression in steatotic livers.

\section{Acknowledgments}

We are grateful to Robin Rycroft at the Language Advisory Service of the University of Barcelona for revising the English text. We thank the Epidemiology and Biostatistics Unit, Barcelona University, for their help in the statistical analyses. C.P. takes part in the Programa de Estabilización de Investigadores (Direcció d'Estratègia i Coordinació del Departament de Salut, Generalitat de Catalunya). A.Z. is a colleague from the Agencia Española de Cooperación Internacional (Madrid, Spain).

Address all correspondence and requests for reprints to: Dr. J. RosellóCatafau, Experimental Hepatic Ischemia-Reperfusion Unit, Instituto de Investigaciones Biomédicas de Barcelona-Consejo Superior de Investigaciones Cientificas, C/ Rosellón 161, Seventh floor, E-08036 Barcelona, Spain. Email: jrcbam@iibb.csic.es; or Dra. C. Peralta, Unitat de Transplantament de Fetge i Viabilitat de l'Empelt, Institut d'Investigacions Biomèdiques August Pi i Sunyer, Consejo Superior de Investigaciones Científicas, E-08036 Barcelona, Spain. E-mail: cpubam@iibb.csic.es.

This work was supported by the Ministerio de Educación y Ciencia (Project Grant SAF 2005-00385) (Madrid, Spain), Ministerio de Sanidad y Consumo (Project Grant PIO60021) (Madrid, Spain), and the Generalitat de Catalunya (2005 SGR/00781 Project) (Barcelona, Spain). Centro de Investigación Biomédica en Red en el Área temática de Enfermedades Hepáticas y Digestivas is funded by the Instituto de Salud Carlos III.

Disclosure Summary: The authors have nothing to disclose.

\section{References}

1. Peralta C, Roselló-Catafau J 2004 The future of fatty livers. J Hepatol 41: $149-151$

2. Behrns KE, Tsiotos GG, DeSouza NF, Krishna MK, Ludwig J, Nagorney DM 1998 Hepatic steatosis as a potential risk factor for major hepatic resection. J Gastrointest Surg 2:292-298

3. Selzner M, Clavien PA 1999 Resection of liver tumors: special emphasis on neoadjuvant and adjuvant therapy. In: Clavien PA, ed. Malignant liver tumors: current and emerging therapies. Malden, MA: Blackwell Science; 137-149

4. Canelo R, Braun F, Sattler B, Klinge B, Lorf T, Ramadori G, Ringe B 1999 Is a fatty liver dangerous for transplantation? Transplant Proc 31:414-415

5. D'Alessandro AM, Kalayoglu M, Sollinger HW, Hoffmann RM, Reed A, Knechtle SJ, Pirsch JD, Hafez GR, Lorentzen D, Belzer FO 1991 The predictive value of donor liver biopsies for the development of primary nonfunction after orthotopic liver transplantation. Transplantation 51:157-163

6. Ding H, Kopple JD, Cohen A, Hirschberg R 1993 Recombinant human insulinlike growth factor-I accelerates recovery and reduces catabolism in rats with ischemic acute renal failure. J Clin Invest 91:2281-2287

7. Holt RI, Crossey PA, Jones JS, Baker AJ, Portmann B, Miell JP 1997 Hepatic growth hormone receptor, insulin-like growth factor I, and insulin-like growth factor-binding protein messenger RNA expression in pediatric liver disease. Hepatology 26:1600-1606

8. Chen JW, Nielsen MF, Caumo A, Vilstrup H, Christiansen JS, Frystyk J 2006 Changes in bioactive IGF-I and IGF-binding protein-1 during an oral glucose tolerance test in patients with liver cirrhosis. Eur J Endocrinol 155:285-292

9. Cusi K, DeFronzo R 2000 Recombinant human insulin-like growth factor I treatment for 1 week improves metabolic control in type 2 diabetes by ameliorating hepatic and muscle insulin resistance. J Clin Endocrinol Metab 85:3077-3084

10. Kelley KM, Oh Y, Gargosky SE, Gucev Z, Matsumoto T, Hwa V, Ng L, Simpson DM, Rosenfeld RG 1996 Insulin-like growth factor-binding proteins (IGFBPs) and their regulatory dynamics. Int J Biochem Cell Biol 28:619-637

11. Holt RI, Baker AJ, Miell JP 1997 The pathogenesis of growth failure in paediatric liver disease. J Hepatol 27:413-423

12. Barreca A, Voci A, Minuto F, de Marchis M, Cecchelli E, Fugassa E, Giordano G, Gallo G 1992 Effect of epidermal growth factor on insulin-like growth factor-I (IGF-I) and IGF-binding protein synthesis by adult rat hepatocytes. Mol Cell Endocrinol 84:119-126 
13. Rogers SA, Miller SB, Hammerman MR 1991 Insulin-like growth factor I gene expression in isolated rat renal collecting duct is stimulated by epidermal growth factor. J Clin Invest 87:347-351

14. van Neck JW, Berghout EM, Vinter-Jensen L, Groffen CA, Cingel V, Dits NF, Drop SL, Flyvbjerg A 2000 The effect of epidermal growth factor and IGF-I infusion on hepatic and renal expression of the IGF-system in adult female rats. J Endocrinol 165:115-122

15. Harada N, Okajima K, Kurihara H, Nakagata N 2007 Stimulation of sensory neurons by capsaicin increases tissue levels of IGF-I, thereby reducing reperfusion-induced apoptosis in mice. Neuropharmacology 52:1303-1311

16. Massip-Salcedo M, Casillas-Ramirez A, Franco-Gou R, Bartrons R, Ben Mosbah I, Serafin A, Roselló-Catafau J, Peralta C 2006 Heat shock proteins and mitogenactivated protein kinases in steatotic livers undergoing ischemia-reperfusion: some answers. Am J Pathol 168:1474-1485

17. Casillas-Ramirez A, Amine-Zaouali M, Massip-Salcedo M, Padrissa-Altés S, Bintanel-Morcillo M, Ramalho F, Serafín A, Rimola A, Arroyo V, Rodés J, Roselló-Catafau J, Peralta C 2008 Inhibition of angiotensin II action protects rat steatotic livers against ischemia-reperfusion injury. Crit Care Med 36: 1256-1266

18. Yamagishi S, Matsumoto T, Yokomaku D, Hatanaka H, Shimoke K, Yamada M, Ikeuchi T 2003 Comparison of inhibitory effects of brain-derived neurotrophic factor and insulin-like growth factor on low potassium-induced apoptosis and activation of p38 MAPK and c-Jun in cultured cerebellar granule neurons. Brain Res Mol Brain Res 119:184-191

19. Bogazzi F, Ultimieri F, Raggi F, Costa A, Gasperi M, Cecconi E, Mosca F, Bartalena L, Martino E 2002 Peroxisome proliferator activated receptor $\gamma$ expression is reduced in the colonic mucosa of acromegalic patients. J Clin Endocrinol Metab 87:2403-2406

20. Zhou Y, Zheng S, Lin J, Zhang QJ, Chen A 2007 The interruption of the PDGF and EGF signaling pathways by curcumin stimulates gene expression of PPAR $\gamma$ in rat activated hepatic stellate cell in vitro. Lab Invest 87:488-498

21. Houde M, Laprise P, Jean D, Blais M, Asselin C, Rivard N 2001 Intestinal epithelial cell differentiation involves activation of $\mathrm{p} 38$ mitogen-activated protein kinase that regulates the homeobox transcription factor CDX2. J Biol Chem 276:21885-21894

22. Nolan CJ, Leahy JL, Delghingaro-Augusto V, Moibi J, Soni K, Peyot ML, Fortier M, Guay C, Lamontagne J, Barbeau A, Przybytkowski E, Joly E, Masiello P, Wang S, Mitchell GA, Prentki M $2006 \beta$-Cell compensation for insulin resistance in Zucker fatty rats: increased lipolysis and fatty acid signaling. Diabetologia 49:2120-2130

23. Liu YQ, Jetton TL, Leahy JL $2002 \beta$-Cell adaptation to insulin resistance. Increased pyruvate carboxylase and malate-pyruvate shuttle activity in islets of nondiabetic Zucker fatty rats. J Biol Chem 277:39163-39168

24. Franklin SC, Moulton M, Sicard GA, Hammerman MR, Miller SB 1997 Insulin-like growth factor I preserves renal function postoperatively. Am J Physiol F 272:257-259

25. Castilla-Cortázar I, Picardi A, Tosar A, Ainzúa J, Urdaneta E, García M, Pascual M, Quiroga J, Prieto J 1999 Effect of insulin-like growth factor I on in vivo intestinal absorption of D-galactose in cirrhotic rats. Am J Physiol 276:G37-G42

26. Tomaszewska R, Dembiński A, Warzecha Z, Ceranowicz P, Konturek SJ, Stachura J 2002 The influence of epidermal growth factor on the course of ischemia-reperfusion induced pancreatitis in rats. J Physiol Pharmacol 53:183-198

27. Zhao TC, Taher MM, Valerie KC, Kukreja RC 2001 p38 triggers late preconditioning elicited by anisomycin in heart: involvement of NF- $\kappa \mathrm{B}$ and iNOS. Circ Res 89:915-922

28. Lang CH, Liu X, Nystrom GJ, Frost RA 2000 Acute response of IGF-I and IGF binding proteins induced by thermal injury. Am J Physiol Endocrinol Metab 278:E1087-E1096

29. Kim HL, Cho YS, Choi H, Chun YS, Lee ZH, Park JW 2009 Hypoxia-inducible factor $1 \alpha$ is deregulated by the serum of rats with adjuvant-induced arthritis. Biochem Biophys Res Commun 378:123-128

30. Powolny AA, Wang S, Carlton PS, Hoot DR, Clinton SK 2008 Interrelationships between dietary restriction, the IGF-I axis, and expression of vascular endothelial growth factor by prostate adenocarcinoma in rats. Mol Carcinog 47:458-465

31. Serafín A, Roselló-Catafau J, Prats N, Gelpí E, Rodés J, Peralta C 2004 Ischemic preconditioning affects interleukin release in fatty livers of rats undergoing ischemia/reperfusion. Hepatology 39:688-698

32. Camargo Jr CA, Madden JF, Gao W, Selvan RS, Clavien PA 1997 Interleukin-6 protects liver against warm ischemia/reperfusion injury and promotes hepatocyte proliferation in the rodent. Hepatology 26:1513-1520

33. Lang CH, Liu X, Nystrom G, Wu D, Cooney RN, Frost RA 2000 Acute effects of growth hormone in alcohol-fed rats. Alcohol 35:148-158

34. Mirpuri E, García-Trevijano ER, Castilla-Cortazar I, Berasain C, Quiroga J,
Rodriguez-Ortigosa C, Mato JM, Prieto J, Avila MA 2002 Altered liver gene expression in CCl4-cirrhotic rats is partially normalized by insulin-like growth factor-I. Int J Biochem Cell Biol 34:242-252

35. Frystyk J, Delhanty PJ, Skjaerbaek C, Baxter RC 1999 Changes in the circulating IGF system during short-term fasting and refeeding in rats. Am J Physiol 277:E245-E252

36. Lang CH, Fan J, Cooney R, Vary TC 1996 IL-1 receptor antagonist attenuates sepsis-induced alterations in the IGF system and protein synthesis. Am J Physiol 270:E430-E437

37. Granado M, Martín AI, López-Menduiña M, López-Calderón A, Villanúa MA 2008 GH-releasing peptide-2 administration prevents liver inflammatory response in endotoxemia. Am J Physiol Endocrinol Metab 294:E131-E141

38. Blomsma MC, de Knegt RJ, Dullaart RP, Jansen PL 1997 Insulin-like growth factor-I in liver cirrhosis. J Hepatol 27:1133-1138

39. Soszynski PA, Frohman LA 1992 Inhibitory effects of ethanol on the growth hormone (GH)-releasing hormone-GH-insulin-like growth factor-I axis in the rat. Endocrinology 131:2603-2608

40. Laron Z 1996 Short stature due to genetic defects affecting growth hormone activity. N Engl J Med 334:463-465

41. Donaghy AJ, Baxter RC 1996 Insulin-like growth factor bioactivity and its modification in growth hormone resistant states. Baillieres Clin Endocrinol Metab 10:421-446

42. Yakar S, Rosen CJ, Beamer WG, Ackert-Bicknell CL, Wu Y, Liu JL, Ooi GT, Setser J, Frystyk J, Boisclair YR, LeRoith D 2002 Circulating levels of IGF-1 directly regulate bone growth and density. J Clin Invest 110:771-781

43. Boisclair YR, Rhoads RP, Ueki I, Wang J, Ooi GT 2001 The acid-labile subunit (ALS) of the $150 \mathrm{kDa}$ IGF-binding protein complex: an important but forgotten component of the circulating IGF system. J Endocrinol 170:63-70

44. Woelfle J, Rotwein P 2004 In vivo regulation of growth hormone-stimulated gene transcription by STAT5b. Am J Physiol Endocrinol Metab 286:E393-E401

45. Jones JI, Clemmons DR 1995 Insulin-like growth factors and their binding proteins: biological actions. Endocr Rev 16:3-34

46. Goda N, Tenno T, Inomata K, Shirakawa M, Tanaka T, Hiroaki H 2008 Intracellular protein delivery activity of peptides derived from insulin-like growth factor binding proteins 3 and 5. Exp Cell Res 314:2352-2361

47. Takaoka M, Smith CE, Mashiba MK, Okawa T, Andl CD, El-Deiry WS, Nakagawa H 2006 EGF-mediated regulation of IGFBP-3 determines esophageal epithelial cellular response to IGF-I. Am J Physiol Gastrointest Liver Physiol 290:G404-G416

48. Bhattacharyya N, Pechhold K, Shahjee H, Zappala G, Elbi C, Raaka B, Wiench M, Hong J, Rechler MM 2006 Nonsecreted insulin-like growth factor binding protein-3 (IGFBP-3) can induce apoptosis in human prostate cancer cells by IGF-independent mechanisms without being concentrated in the nucleus. J Biol Chem 281:24588-24601

49. Chen X, Ferry Jr RJ 2006 Novel actions of IGFBP-3 on intracellular signaling pathways of insulin-secreting cells. Growth Horm IGF Res [Erratum (2006) 16:276] 16:41-48

50. Shaikh S, Bloomfield FH, Bauer MK, Phua HH, Gilmour RS, Harding JE 2005 Amniotic IGF-I supplementation of growth-restricted fetal sheep alters IGF-I and IGF receptor type $1 \mathrm{mRNA}$ and protein levels in placental and fetal tissues. J Endocrinol 186:145-155

51. Liao L, Dearth RK, Zhou S, Britton OL, Lee AV, Xu J 2006 Liver-specific overexpression of the insulin-like growth factor-I enhances somatic growth and partially prevents the effects of growth hormone deficiency. Endocrinology 147:3877-3888

52. Donaghy AJ, Delhanty PJ, Ho KK, Williams R, Baxter RC 2002 Regulation of the growth hormone receptor/binding protein, insulin-like growth factor ternary complex system in human cirrhosis. J Hepatol 36:751-758

53. Casillas-Ramírez A, Mosbah IB, Ramalho F, Roselló-Catafau J, Peralta C 2006 Past and future approaches to ischemia-reperfusion lesion associated with liver transplantation. Life Sci 79:1881-1894

54. Ramírez I, Tebar F, Grau M, Soley M 1995 Role of heterotrimeric G-proteins in epidermal growth factor signalling. Cell Signal 7:301-311

55. Kholodenko BN, Demin OV, Moehren G, Hoek JB 1999 Quantification of short term signaling by the epidermal growth factor receptor. J Biol Chem 274:30169-30181

56. Marino M, Spagnuolo S, Cavallini M, Terenzi F, Mangiantini MT, Leoni S 1996 EGF responsiveness of hepatocytes after partial hepatectomy. Cell Signal 8:555-559

57. Angulo P 2002 Nonalcoholic fatty liver disease. N Engl J Med 346:1221-1231

58. Veteläinen R, van Vliet A, Gouma DJ, van Gulik TM 2007 Steatosis as a risk factor in liver surgery. Ann Surg 245:20-30

59. Farrell GC, Teoh NC, McCuskey RS 2008 Hepatic microcirculation in fatty liver disease. Anat Rec (Hoboken) 291:684-692 